\title{
KONSEP 'URF SEBAGAI SUMBER HUKUM DALAM ISLAM
}

\author{
Darnela Putri \\ Universitas Islam Indonesia Yogyakarta, Indonesia \\ darnelaputri96@gmail.com
}

Received:12-04-2020; Revised:08-12-2020; Accepted: 22-12-2020;

\section{ABSTRACT}

Problems of an increasingly complex society require proper resolution. Islamic law that makes the Al-Qur'an and al-Hadith as the main reference there is a time does not explain Islamic law in detail, while Muslims must live their lives according to Islamic rules, norms and laws are required to always be relevant to the development of increasingly complex times. Ijtihad is needed in dealing with this problem, one of the products of ijtihad is $t$ urf which can be used as a solution and as a source of Islamic law. The method used in this study is a descriptive qualitative analysis research method and includes a type of research that is literature study. Now 'Urf is something that is known by many people and done by them, both from words or deeds or something left behind. This article discuss the concept of urf which can be used as a source of Islamic law. The results of the discussion of the concept are First, 'Urf must apply continuously or mostly apply. Second, 'Urf which is the legal source for an action must be present at the time the action is held. Third, there is no affirmation (nash) that is contrary to 'URF. Fourth, the use of 'urf will not lead to the exclusion of certain texts from the shari'ah because the texts of shara' must take precedence over 'urf.

Keywords: The 'urf Concept, Source of Islamic Law, and Ijtihad Ulama.

\section{INTISARI}

Permasalahan masyarakat yang semakin kompleks menghendaki adanya penyelesaian dengan tepat namun tetap sesuai dengan hukum Islam berdasarkan Al-Qur'an dan Al-hadist sebagai rujukan utamanya. Terkadang ada yang tidak dijelaskan oleh keduanya, ummat Islam harus menjalankan kehidupannya sesuai aturan, norma dan hukum Islam dituntut untuk selalu relevan terhadap perkembangan zaman yang semakin kompleks, maka diperlukan ijtihad para ulama dalam menangani problem ini yang salah satu produk ijtihadnya adalah ' $u r f$. ' $U r f$ dapat dijadikan solusi dan sebagai salah satu sumber dalam hukum Islam. 'Urf ialah sesuatu yang telah diketahui oleh orang banyak dan mereka mengerjakannya. Artikel ini akan membahas konsep 'urf yang dapat dijadikan sebagai sumber hukum Islam tersebut. Adapun hasil pembahasan dari konsep tersebut adalah Pertama, 'Urf harus berlaku secara kontiniu. Kedua, 'Urf yang dijadikan sumber hukum bagi suatu tindakan harus terdapat pada waktu diadakannya tindakan tersebut. Ketiga, Tidak terdapat penegasan (nash) yang berlawanan dengan 'urf. Keempat, 'urf digunakan dengan tidak mengesampingkan nash yang pasti dari syari`at. Sebab nash-nash syara` harus diutamakan atas 'urf.

Kata Kunci: Konsep 'urf, Sumber Hukum Islam, dan Ijtihad Ulama. 


\section{A. Pendahuluan}

Permasalahan masyarakat semakin kompleks menghendak untuk adanya penyelesaian dengan tepat. Tidak hanya mengetahui antara benar dan salah, akan tetapi penyelesaian terhadap problematika ini diharapkan juga dapat membawa kemaslahatan bagi masyarakat. Hukum Islam menjadikan al-Qur'an dan al-Hadist sebagai rujukan utamanya diminta untuk selalu relevan terhadap perkembangan zaman yang semakin kompleks ini. ${ }^{1}$ Tidak semua hukum Islam dijelaskan secara terperinci oleh Alqur'an dan hadits, sedangkan umat Islam harus menjalankan kehidupannya sesuai aturan, norma dan hukum Islam. Untuk menjawab problem tersebut, para ahli mengerahkan segenap kemampuan nalarnya untuk mendapatkan solusi yang tepat pada setiap permasalahan yang ada. Inilah yang disebut dengan ijtihad. ${ }^{2}$

Dalam berijtihad, nash-nash yang belum tegas maknanya dipelajari oleh ulama, kemudian dijelaskan dan dikeluarkan hukumnya sehingga menjadi lebih jelas. Maksud dari Nash-nash yang belum jelas dalam kajian ushul fiqh disebut dengan nash zhanni. Nash zhanni inilah yang dikaji oleh para ulama agar lebih jelas maknanya dan dapat dipahami apa maksud dari ayat tersebut bagi umat. Pengeimplementasian ijtihad pada kasus yang tidak tercantum dengan tegas maksudnya pada nash atau tidak qath'i baik itu wurud maupun dalalatnya, akan selalu ada kaitannya dengan nash tersebut dalam menjabarkan kekuatannya dan hanya menjelaskan maksud nash tersebut. Ijtihad terhadap nash juga dapat memudahkan kita dalam memahami maksud dari adanya hukum (Maqashid Syariah). ${ }^{3}$

Dalam kehidupan masyarakat ada kebiasaan alias tradisi tertentu ('urf) yang berlaku, maka seorang mujtahid akan mempelajari terkait ada atau tidaknya nash yang mengatur, atau menyatakan pelanggaran perihal kasus tersebut serta merumuskan dan menerapkan hukum bagi kasus yang terdapat pada nash. Apabila kebiasaan atau tradisi tertentu ('urf) yang berlaku tidak memiliki tantangan dengan nash, maka boleh menjalani ('urf) tersebut karena dinilai mengandung maslahat, sedangkan bagi kebiasaan yang berlaku pada masyarakat jika tidak terdapat acuan pada nash atau bahkan tidak sesuai dengan nash, maka para mujtahid dapat menganalisa dan memberikan dasar hukum terhadap keberlakuan kasus tersebut. ${ }^{4}$ Maka penulis merasa penting untuk mengkaji permasalahan ini yang dapat menjadi solusi dari problematika umat yang semakin hari semakin komplek ragamnya. Artikel ini akan mengkaji lebih dalam lagi mengenai tradisi tertentu ('urf) yang dapat dijadikan sebagai salah satu sumber hukum Islam yang dikategorikan sebagai salah satu bentuk dari ijtihad para ulama.

\section{B. Metode Penelitian}

Artikel ini akan mengkaji lebih dalam lagi mengenai tradisi tertentu ('urf) yang dapat dijadikan sebagai salah satu sumber hukum Islam yang dikategorikan sebagai salah satu bentuk dari ijtihad para ulama. Metode penelitian yang digunakan dalam penelitian ini adalah metode penelitian analisis deskriptif kualitatif dan termasuk kejenis penelitian yang bersifat studi pustaka. Data penulis peroleh melalui pencarian, pengklasifikasian, penyeleksian, penganalisaan

${ }^{1}$ Faiz Zainuddin, “Konsep Islam Tentang Adat: Telaah Adat Dan Urf Sebagai Sumber Hukum Islam”, Jurnal Lisan Al-Hal, Volume 9, No. 2, Desember 2015, 389-390.

${ }^{2}$ Amir Syarifuddin, Ushul Fiqh, Jilid 2, (Jakarta: Prenada, 2009), 323.

3 Galuh Nashrullah Kartika Mayangsari Rofam, "Penerapan Konsep ’Urf Dalam Kitab Sabilal Muhtadin (Kajian Terhadap Pemikiran Muhammad Arsyad Al Banjari)", Al-Iqtishadiyah, Jurnal Ekonomi Syariah Dan Hukum Ekonomi Syariah, Volume: IV, Nomor I, Juni 2018, 1-2.

${ }^{4}$ Abdul Wahab Khallaf, Ilmu Ushul Fiqh, (Jakarta: Rineka Cipta, 2012), 105. 
sehingga dapat disajikan dengan rangkum mengenai bahasan ini. Sumber data diporeleh melalui studi pustaka dengan pencarian sumber melalui buku, jurnal-jurnal, artikel ilmiah yang telah penulis rinci dan analisa sesuai dengan fokus dan relevan pada bahasan artikel ini.

\section{Hasil Dan Pembahasan}

1. Defenisi 'Urf

Definisi 'urf dilihat secara bahasa memiliki arti adalah paling tingginya sesuatu. ${ }^{5}$ Allah SWT berfirman dalam Q.S. Al-`Araf: 46 yang artinya:

"Dan diatas (al-A`raf) itu ada orang-orang yang mengenal masing-masing dari dua golongan itu dengan tanda-tanda mereka."

Adapun pendapat lain yang mengatakan 'urf secara bahasa itu kelazimanan atas suatu kebiasaan yang dilakukan. ${ }^{6}$ Sedangkan 'urf menurut istilah yaitu sesuatu yang menjadi tradisi dikalangan manusia dan mereka menjalankan dengan perbuatan dan ucapan yang sudah terbiasa diantara mereka, hal ini mencakup 'urf amaly dan qauly. Dengan kata lain, 'urf merupakan apa yang dikenal manusia dan berlaku padanya, baik berupa perkataan, perbuatan ataupun meninggalkan sesuatu. ${ }^{7}$ Dapat diartikan 'urf ialah sesuatu yang telah diketahui oleh orang banyak dan dikerjakan oleh mereka, baik itu dari ucapan ataupun perlakuan atau sesuatu yang ditinggalkan. ${ }^{8}$

Abdul Wahhab Khallaf mendefenisikan 'urf sebagai "sesuatu yang dikenali dan dilakukan oleh manusia tersebut, baik segi perkataan, perbuatan termasuk juga pada suatu yang mereka tinggalkan." "Urf memiliki kunci pengertian bahwa ia tidak melihat dari segi kuantitas pengulangan suatu perbuatan yang dilakukan, namun tepatnya dari segi apakah perbuatan tersebut sudah dikenali dan diakui oleh orang banyak. ${ }^{10}$ Dalam nyatatanya, banyak dari ulama` fiqh mengartikan 'urf sebagai kebiasaan yang dilakukan banyak orang (kelompok) dan timbul dari kreatifitas atau imajinatif dalam membangun nilai-nilai budaya. Sisi lainnya, baik dan buruknya kebiasaan tidak menjadi persoalan yang begitu penting asal dilakukan secara bersama, maka kebiasaan yang seperti ini termasuk kategori 'urf. ${ }^{11}$

Secara defenitif ' $U r f$ dalam ilmu ushul al-fiqh disinonimkan dengan 'adat setelah diserap ke dalam bahasa Indonesia, yaitu menjadi "Adat". Dapat dilihat dari penjelasan Abdul Wahab Khallaf, yang menegaskan secara syari'at, tidaklah terdapat perbedaan antara 'urf dan 'adat. ${ }^{12}$ Jika ditelisik pada segi penggunaan dan akar katanya, Akar kata 'adat, yaitu 'ada, ya'údu, yang berarti pengulangan. Bila sesuatu (baru) dilakukan satu kali, belum dapat dinamakan sebagai 'adat. Adapun kata 'urf, pengertiannya tidaklah melihat dari segi berulangkalinya suatu perbuatan dilakukan, tetapi apakah suatu ucapan, perbuatan itu dikenal atau tidak oleh banyak orang. Jelasnya lagi, 'adat sesuatu yang berulangkali, dan 'urf sesuatu yang dikenal.

\footnotetext{
${ }^{5}$ Faiz Zainuddin, “Konsep..., 391.

${ }^{6}$ M. Umar, Study Ushul Fiqh, (Jakarta: 1987), 109.

${ }^{7}$ Totok Jumantoro, Kamus Ilmu Ushul Fiqh, (Jakarta: Amzah, 2005), 1.

8 Agung Setiyawan, "Budaya Lokal Dalam Perspektif Agama: Legitimasi Hukum Adat ('Urf) Dalam Islam, Esensia Vol. XIII, No. 2 Juli 2012, 214.

9 'Abdul Wahhab Khallaf, 'Ilm Al-Ushul Al-Fiqh, (Mesir : Dar Al-Qalam, 1978), Cet. Ke-12, 89.

${ }^{10}$ Amir Syarifuddin, Ushul Fiqh,(Jakarta: Logos Wacana Ilmu, 1997), 364.

${ }^{11}$ Ifrosin, Fiqh Adat (Tradisi Masyarakat Dalam Pandangan Fiqh), (Jawa Tengah: Mukjizat. 2007$), 6$.

12 'Abdul Wahhab Khallaf, 'Ilm al-Ushul al-Fiqh, 89.
} 
Amir Syarifuddin berpendapat seperti di ini. “...tidak ada perbedaan mendasar karena kedua kata itu pengertiannya sama, yaitu: suatu perbuatan yang telah berulang-ulang dilakukan menjadi diketahui dan diakui banyak orang. Sebaliknya, karena perbuatan itu sudah dikenal dan diakui orang banyak, maka perbuatan itu dilakukan orang secara berulang kali. Kendatipun dua kata di atas dapat dibedakan tetap perbedaannya tidak begitu berarti."13

Ditegaskan dari penjelasan Amir ini, bahwa tidaklah berarati membedakan 'urf dan 'adat. Karena kedua kata itu, segi bentuk memang berbeda, namun mempunyai kesamaan makna. Dijelaskan lebih lanjut oleh Amir bahwa kata 'urf digunakan dengan memandang pada kualitas perbuatan yang dilakukan yaitu diakui, diketahui dan diterima oleh orang banyak. Dengan demikian, kata 'urf mengandung konotasi baik. Tampak pada defenisi 'urf yang dirumuskan oleh Badran, sebagaimana dikutip oleh Amir, berikut ini, "Apa-apa yang dibiasakan dan diikuti oleh orang banyak, baik dalam bentuk ucapan atau perbuatan, berulang-ulang dilakukan, sehingga berbekas dalam jiwa mereka dan diterima baik oleh akal mereka."14

Pada akhirnya, diuraikan oleh Amir pendapat dari Musthafa Syalabi yang bahwa; perbedaan 'urf dan 'adat, tidaklah berada pada kandungan maknanya (netral atau tidak netral), namun pada lingkup pengaplikasiannya. Kata 'urf selalu digunakan untuk jama'ah atau golongan, sedangkan kata 'adat dapat digunakan untuk sebagian orang di samping berlaku pula untuk golongan. Apa yang telah dilakukan (menjadi kebiasaan) seseorang, maka perbuatan itu dapat dikatakan sebagai " 'adat orang itu, namun tidak dapat dikatakan 'urf orang itu."15

\section{Kedudukan 'Urf Dalam Sumber Hukum}

Dari sisi historisnya, 'urf dipakai pada kalangan ahli fiqh saat berkembangnya permasalahan yang menyangkut furu'iyah. Terdapat dalam nash tetapi sebagian hukum dalam nash sudah menjadi kebiasaan ('urf) masyarakat kala itu. Kebiasaan tersebiut bisa diterima oleh Islam selama tidak adanya tentangan dalam nash. ${ }^{16}$

Segala hukum jika didasarkan pada adat, lambat laun seiring waktu berjalan dan berubahnya tempat akan mengalami perubahan disebabkan masalah baru bisa berubah sebab perubahan masalah asal. Oleh karena itu, para ulama fikih berkata: "Perbedaan itu adalah pada waktu dan masa, bukan pada dalil dan alasan. ${ }^{17}$ Jumhur fuqaha' mengatakan bahwa al-Urf merupakan hujjah dan dianggap sebagai salah satu sumber hukum syariat. Adapun sandaran dari mereka ada pada hal berikut ${ }^{18}$ :

\section{a. Firman Allah SWT}

Allah SWT berfiman dalam QS. Al-A'Raf 7:199. Artinya "Jadilah engkau pemaaf dan suruhlah orang mengerjakan yang makruf serta berpalinglah dari pada orang-orang yang bodoh." Kata al-urfi dalam ayat tersebut, dimana umat manusia disuruh mengerjakanmya, oleh para ulama' Ushul Fiqh dipahami sebagai sesuatu yang baik dan telah menjadi kebiasaan masyarakat.

\section{b. Hadis}

"Sesuatu yang dianggap oleh orang muslim itu baik maka Allah menganggap perkara itu baik pula" maksud dari hadist tersebut adalah semua perbuatan yang terjadi di masyarakat

\footnotetext{
${ }^{13}$ Amir Syarifuddin, Ushul Fiqh, jilid 2, (Jakarta : Logos, 2001), Cet. Ke-2, 364.

${ }^{14}$ Amir Syarifuddin, Ushul Fiqh, jilid 2.., 364.

15 Ibid.

${ }^{16}$ Musa Aripin, Eksistensi..., 207.

17 Abdul Wahab Khallaf, Ilmu Ushul Fiqh (Kaidah Hukum Islam), (Jakarta:Pustaka Amani), 118-119.

${ }^{18}$ Rasyad Hasan Khalil, Tarikh Tasryi',(Jakarta: Amzah, 2009), 169.
} 
tertentu apabila yang menilai adalah seorang mukmin sejati dan dinilai baik suatu perbuatan tersebut maka perbuatan tersebut dianggap baik pula oleh Allah SWT.

\section{c. Aspek Kebiaaan Orang Arab Sangat Diperhatikan Oleh Syariat Islam Dalam Menetapkan Hukum.}

Kebiasaan orang Arab sangat diperhatikan dalam menetapkan hukum pada syariat Islam. Penetapan dilakukan guna mewujudkan kemaslahatan bagi masyarakat umum, seperti akad salam dan mewajibkan denda kepada pembunuh yang tidak disengaja. Islam juga membatalkan beberapa kebiasaan buruk yang membahayakan, contohnya anak perempuan dikubur dan dijauhkannya kaum wanita dari harta warisan. Semua ini pembuktian bahwa syariat Islam mengakui keberadaan adat istiadat yang baik. ${ }^{\mathbf{1 9}}$

\section{d. Syariat Islam Memiliki Prinsip Menghilangkan Segala Kesusahan}

Menghilangkan segala kesusahan salah satu prinsip dari syariat Islam. Islam senang memudahkan urusan manusia. Mewajibkan orang untuk meninggalkan sesuatu yang sudah menjadi adat kebiasaan mereka sama artinya menyusahkan mereka. Sebagaimana Firman Allah SWT QS. Al-Hajj 22:78 "Dan Dia sekali-kali tidak menjadikan untuk kamu dalam agama suatu kesempitan". Kendatipun demikian tentu ada syarat dan ketentuannya untuk bisa diterima.

\section{e. Syariat Islam Tradisi Dalam Masyarakat}

Dasarnya syariat Islam dari masa awal, banyak adat atau tradisi yang baik dalam masyarakat diakui dan diterima selama tradisi itu tidak bertentangan dengan sumber utama hukum Islam yaitu Al-qur'an dan Hadist. Datangnya Islam bukanlah sama sekali untuk menghapus kebiasaan yang telah menyatu dengan masyarakat, tetapi secara selektif ada yang diakui dan dilestarikan serta adapula yang dihapuskan. ${ }^{20}$

3. Pembagian Dan Macam-Macam 'Urf

a. 'Urf Ditinjau Dari Aspek Cakupan Kuantitas Banyak Dan Sedikitnya Orang Yang Memakai

1) 'Urf Umum

'Urf umum adalah 'urf didefiniskan sebagai kebiasaan yang berlaku untuk semua orang pada semua tempat dalam suatu perkara, seperti halnya akad istisna' yang sudah menjadi ketentuan umum demi memenuhi kebutuhan, jual beli muatha', pemesanan barang-barang kehidupan dan sebagainya. Cara pemesanan disetiap tempat dan untuk waktu sekarang meliputi semua barang seperti pemesanan pabrik, kapal dan bangunan. ${ }^{21}$

2) 'Urf Khusus

'Urf ini dipakai pada tempat tertentu oleh golongan tertentu. 'Urf khas banyak macamnya. Diikuti oleh berubah-ubahnya keperluan orang-orang dan cara untuk memenuhinyapun berbeda-beda. Dapat dilihat pada kasus pembayaran dimuka sebagian honorium bagi pembela perkara-perkara, sebagiannya lagi bergantung kepada kemenangan perkara yang dihadapinya dan sesudah mendapat keputusan terakhir serta

${ }^{19}$ Musa Aripin, “Eksistensi Urf Dalam Kompilasi Hukum Islam”, Al-Maqasid, Volume 2 Nomor 12016,

212.

${ }^{20}$ Musa Aripin, "Eksistensi..., 212-213.

${ }^{21}$ Faiz Zainuddin, "Konsep..., 394. 
dilaksanakannya keputusan tersebut. ${ }^{22}$ Kalangan para ulama menyatakan tidak ada perbedaan diantara 'urf khusus dan 'urf umum dari aspek keabsahannya sebagai sumber hukum, 'jika urf khusus dan 'urf umum telah berlaku umum dan dilakukan secara terus menerus bahkan Imam Abu Hanifah menegaskan tentang qiyas dapat ditinggalkan dengan berlakunya 'urf secara umum dan'urf juga dapat men-takhsis dalil syar'i, seperti akad istishna', akad salam. ${ }^{23}$

\section{b. Urf Ditinjau Dari Peletakannya Atau Lapangan Pemaknaannya}

1) 'Urf Qauliy (kata-kata)

'Urf ini biasa terjadi apabila suatu kata atau susunan kata-kata dipakai secara biasa oleh masyarakat dalam mengartikan suatu hal tertentu. Jadinya skata-kata tersebut bila diucapkan, maka secara mutlak (tanpa asosisiasi pikiran tertentu) maka dari kata yang diucapakan dapat dimengerti oleh pikiran secara cepat dan langsung oleh orang yang mendengarnya. Seperti kita mendengar kata dirham yang berarti uang yang berlaku disuatu negeri. Walaupun uang kertas juga dimaknai uang. Pada mulanya arti dirham ialah uang logam yang dicap dengan mempunyai berat tertentu. ${ }^{24}$

Kalau maksud yang disampaikan memerlukan asosiasi pikiran tertentu atau simbol tertentu dalam pemahamannya, maka tidak dapat disebut 'urf melainkan majaz. Seperti apabila ada oang yang mengatakan "Mahkamah telah memutuskan begini". Maka dengan melalui asosiasi pikiran, yang dimaksud adalah tempat hakim memeriksa. Kata-kata yang ada pada contoh ini tidak termasuk 'urf kata-kata yang dianggap sebagai bahasa tertentu, dimana pengertian secara hakikat dapat diperoleh dari kata itu sendiri. ${ }^{25}$

2) 'Urf Fi liy (perbuatan)

'Urf perbuatan merupakan kebiasaan tertentu yang menjadi kebiasaan banyak orang. Dalam tradisi masyarakat Arab, 'urf ini dapat kita lihat pada kegiatan jual beli tanpa ijab dan qabul atau dalam fiqih dikenal dengan sebutan bai al-mu'atha, merupakan hal yang sudah umum terjadi. Kebiasaan ini mudah dijalankan dan lumrah serta hampir terjadi pada semua kalangan masyarakat. Tak heran bila qaulmukhtar melegalkan jenis transaksi ini, tetapi dengan catatan hanya terbatas pada barang yang harga nominalnya rendah muhaqqirat, sebab tradisi seperti ini telah menjadi kebiasaan masyarakat yang sulit dihindari. ${ }^{26}$

Contoh lain dapat kita lihat pada transaksi perwakilan yang dikenal dengan istilah (wakalah). Misalnya ada seseorang yang mewakilkan pembelian daging kepada orang lain, tetapi dengan kta-kata yang bermakna tidak khusus alias umum. Diucapkan "tolong belikan saya daging", tapi tidak dijelaskan spesifikasi daging apa yang di mau. Namun, karena dagiang yang biasa dikonsumsi oleh masyarakat tersebut daging sapi, maka orang yang dimintai tolong tadi tidak boleh membelikan daging lainnya selain daging sapi sebab ungkapan "tolong belikan saya daging" dari orang yang meminta

${ }^{22}$ Ahmad Hanafi, Pengantar dan Sejarah Hukum Islam, (Jakarta: PT Bulan Bintang. 1991), 91.

${ }^{23}$ Ibid.

${ }^{24}$ Muhammad Siddiqi Bin Ahmad, Al-Wajiz fi Idhah al-Qawaid, (Bairut: Muassasah al-Rissalah, 1983), 160.

${ }^{25}$ Faiz Zainuddin, “Konsep..., 395.

${ }^{26}$ Ibid. 
tolong ialah mengindikasikan pesannya adalah daging sapi, sesuai dengan kebiasaan yang berlaku di kawasan itu. ${ }^{27}$

\section{c. Kedudukan 'Urf Perkataan (Qauliy) Dan 'Urf Perbuatan (Fi'Liy)}

1) Kedudukan 'Urf Perkataan (Qauliy)

'urf perkataan dalam hukum Islam memiliki kedudukan bahwa kata-kata yang diucapkan oleh seorang mustilah diartikan sesuai dengan bahasa dan kebiasaan yang berlaku pada waktu diucapkannya, meskipun berlawanan dengan arti hakiki yang semula, karena kebiasaan yang datang kemudian telah memindahkan kata-kata tersebut kepada pengertian lain yang merupakan hakiki. ${ }^{28}$ Sekiranya pengertian kata-kata tersebut harus diartikan bahasa dan bukan pengertian menurut 'urf yang dituju oleh kebiasaan pembicara, maka hal ini membebani kata-katanya dengan baik berupa perikatan pengakuan, sumpah talak, dan lain-lain. Berdasarkan hal ini maka para fuqhaha' menetapkan kaidah hukum yang berbunyi: "Pengertian hakikat dapat ditinggalkan berdasarkan kebiasaan". ${ }^{29}$

Boleh jadi pengertian "talak", dalam 'urf hanya berarti satu ancaman, bukan talak yang tertera dalam kitab fiqh. Jadi yang menjadi pegangan dari permaslahan ini adalah pengertian menurut 'urf ketika diucapkan, beserta semua akibat-akibat hukum timbul dari pengertian tersebut. ${ }^{30}$ Jika dipandang dari segi ijma' ulama`maka 'urf Menurut Imam al-Syaukani: 'urf qauliy sangat mempengaruhi didalam memahami hukum-hukum syar`i. Karena perkataan seseorang diarahkan kepada bahasa 'urf-nya. Dalam arti, yang dijadikan pijakan untuk memaknai nash-nash syar`i dengan makna yang dimaksud itu adalah tidak lepas dari 'urf. Imam al-Syatibi menuturkan dalam kitab al-muwafakat bahwa menurut kesepakatan Ulama' hukum Islam hanya berpegang kepada kemaslahatan manusia. Oleh karena itu, maka wajib menggunakan 'urf sebagai sandaran hukum, sebab 'urf juga bisa menciptakan kemaslahatan. Disebutkan juga oleh beliau, jika secara asal adanya pensyariatan hukum adalah merupakan sebab adanya kemaslahatan maka wajib bagi praktisi hukum untuk menciptakan kemaslahatan tersebut dengan cara berpegang kepada 'urf. ${ }^{31}$

2) Kedudukan Prilaku Yang Telah Menjadi Tradisi ('Urf Fi'Liy)

Penjelasan para fuqoha' perihal kedudukan 'urf fi'liy ialah untuk lapangan perbaikan-perbaikan perseorangan maupun untuk hubungan keperdataan. 'Urf memiliki kedudukan penting dalam menentukan hukum dan membatasi akibat perikatan dan tanggungan kepada keadaan yang bisa berlaku, selama tidak berlawanan dengan ketentuan syara'. Jika terdapat perlawanan maka akan ada pembahasan khusus. ${ }^{32}$ Dengan demikian,'urf dilihat sebagai sumber hukum dan dalil yang sah selama tidak ada dalil syara' yang lain. Imam al-Syarkhasi mengatakan kebiasaan sama dangan apa yang ditetapkan dalam nash (al-ta yin bil 'urfi ka-ta yin bin Nassi). ${ }^{33}$

${ }^{27}$ Ibid, 395-396.

${ }^{28}$ Faiz Zainuddin, “Konsep..., 396.

${ }^{29}$ Hasyiyah Raddul Muhtar, Juz I, hlm 39, al-Maktaba as-Syamilah.

${ }^{30}$ Faiz Zainuddin, “Konsep..., 396.

${ }^{31}$ Abu Ishaq Ibrahim Bin Musa al-Syatibi, Al-Muafakat fi Ilmi Ushul Fiqh, (Beirut: Darul Fikr, 2005), Juz II, 212

${ }^{32}$ Faiz Zainuddin, “Konsep..., 397-398.

${ }^{33}$ Ibrahim Muhammad Mahmud Hariri, al-Madkhal ila Qowaidul Fiqhiyah, 113. 
Contoh untuk perihal di atas, pengaruh kebiasaan terhadap kedudukan tindakantindakan hukum dan perikatan-perikatan hukum ialah mengenai besarnya nafkah istri yang menjadi kewajiban suami, sebab hal ini tergantung pada kadar yang biasa berlaku pada suami istri dan menurut kadar kemampuan (kaya atau miskin) keduanya. Jadi apabila keduanya termasuk keluarga sedang, maka besarnya nafkah menurut tingkatannya. Dan kalau kaya atau miskin, maka menurut tingkatan kekayaan dan kemiskinannya. Jadi kebiasaan orang banyak dalam cara-cara hidup telah mengakibatkan batas-batas tertentu kepada seorang suami dalam memberikan besarnya nafkah yang telah diwajibkan oleh syara: ${ }^{34}$

Jika suatu hukum ditetapkan berdasarkan kebiasaan, maka hukum tersebut bisa saja berubah sesuai pada kebiasaan tersebut dan dalam kaidah hukum Islam suatu hukum dapat berubah bergantung pada illatnya. Maka berlaku aturan yang berbunyi "(la yunkaru taghayyurul ahkam bitaghayyuril azman)" yang memiliki makna perubahan hukum karena perubahan zaman tidak dapat diingkari. ${ }^{35}$

\section{d. 'Urf Dipandang Dari Aspek Diperhitungkan Atau Tidak Diperhitungkan Sebagai} Landasan Hukum

1) 'Urf yang Tidak Baik (Fasid)

'Urf fasid (tidak baik) merupaka suatu kebiasaan bagi orang tetapi bertentangan dengan syara' atau bisa juga menghalalkan yang haram, membatalkan yang wajib. Misalnya kebiasaan orang-orang melakukan perbuatan mungkar di dalam pesta-pesta. Secara hukum,'urffasid tidak wajib dipelihara karena dengan memeliharanya dapat mengakibatkan adanya tentangan dengan dalil syar’i atau bahkan bisa membatalakan dalil syar`i. Karena kebiasaan yang fasid ini dapat memperbolehkan aqad yang dilarang. ${ }^{36}$

2) 'Urf yang Baik (Shahih)

'Urf shahih (baik) yaitu kebiasaan yang dilakukan oleh orang-orang dan tidak bertentangan dengan suatu dalil syar’i tidak menghalalkan sesuatu yang diharamkan. Misalnya kebiasaan orang-orang dalam memesan suatu barang sesuai dengan kebiasaan setempat asal tidak menyalahi hukum syara', pemberian perhiasan emas kepada seorang istri biasanya tidak dimasukkan ke dalam bagian maskawin, dan sebagainya. Hukumnya 'urf shahih harus dijaga dan dipelihara didalam menetapkan hukum, memutuskan hukum dan sebagainya. ${ }^{37}$ Para Mujtahid harus memelihara didalam tasysri'-nya itu dan bagi hakim memelihara pada hukumnya. Karena apa yang saling diketahui orang dan beserta apa yang dijalani orang itu dapat dijadikan hujjah, kesepakatan dan kemaslahatan mereka. Diwajibkan untuk memeliharanya selama tidak memiliki tantangan dengan dalil syari'. ${ }^{38}$

\section{Syarat-Syarat Pemakaian 'Urf Sebagai Sumber Hukum}

Secara historisnya, 'urf digunakan di kalangan ahli fiqh dimulai dari berkembangnya permasalahan yang menyangkut furu'iyah yang terdapat dalam nash tetapi sebagian hukum yang

\footnotetext{
${ }^{34}$ Ahmad Hanafi, Pengantar Sejarah Hukum Islam, (Jakarta: PT Magenta Bhakti Guna, 1989), 94

${ }^{35}$ Abdul Aziz Muhammad Azam, al-Qowaidul Fiqhiyah. (Mesir: Darul Hadist, 2005), 198.

${ }^{36}$ Faiz Zainuddin, “Konsep..., 399.

${ }^{37}$ Abdul Wahab Khallaf, Ushul Fiqh, (Jakarta: Dar Al-Kutub Al-Islamiyah, 2010), hlm, 89.

${ }^{38}$ Ibid, 89.
} 
ada dalam nash sudah menjadi kebiasaan ('urf) masyarakat ketika itu sehingga kebiasaan yang sudah menjadi tradisi itu dapat diterima oleh Islam selama tidak bertentangan dengan nash. ${ }^{39}$

Dikuatkan dari pendapat al-Syathibi sebagaimana dikutipnya sendiri, Ghanim al-Sadlan menjelaskan bahwa pentingnya mempertimbangkan 'urf dalam pengembangan hukum ialah karena hukum bertujuan untuk menciptakan kemaslahatan bagi manusia. Adat atau 'urf merupakan tempat apa yang dikehendaki oleh syari'at. Disebabkan itu, segala sesuatu yang dianggap baik (maslahah) menurut 'urf maka ia juga dipandang baik berdasarkan syari'at. ${ }^{40}$ 'Urf' supaya bisa dijadikan sebagai salah satu sumber dari hukum Islam memiliki kriteria yang harus dipertimbangkan, ada empat syarat diantanya: ${ }^{41}$

Pertama, 'Urf harus terus menerus berlaku atau kebanyakan berlaku. Maksudnya adalah bahwa 'urf berlaku untuk semua peristiwa tanpa kecuali, sedang yang dimaksud dengan kebanyakan berlakunya ialah bahwa 'urf tersebut berlaku dalam kebanyakan peristiwa, banyak juga dalam prakteknya, dan bukan kebanyakan hitungan peristiwa statistiknya saja. Jika sesuatu sama kekuatannya antara sesuatu yang dibiasakan dengan tidak dibiasakan, maka disebutlah perkara tersebut dengan 'urf mustarak. 'Urf seperti itu tidak bisa dijadikan sebagai sandaran dan dalil dalam menentukan hukum hak dan kewajiban. Karena perbuatan orang banyak pada suatu waktu biasa dianggap sebagai dalil dan bisa saja pada waktu lainnya dianggap sebagai penentang dalil, maka peninggalannya pada waktu yang lain dianggap sebagai penentang dalil yang lain. Lebih ke ambigu jadinya. ${ }^{42}$

Kedua, 'Urf yang dijadikan sebagai sumber hukum terhadap suatu tindakan harus terdapat pada waktu diadakannya tindakan itu. Jadi bagi 'urf yang hadir dikemudian dari suatu tindakan tidak biasa dipegangi, dan hal ini untuk menjaga kesetabilan ketentuan suatu hukum. Misalnya, kalau kata-kata "sabilillah" dalam pembagian harta zakat menurut 'urf pada suatu ketika diartikan semua keperluan jihad untuk agama, atau semua jalan kebaikan dengan mutlak, begitu juga kata-kata "ibnusabil" diartikan kepada orang yang kehabisan bekal dalam perjalanan. Kemudian pengertian yang dibiasakan tersebut berubah, sehingga sabilillah diartikan mencari ilmu semata-mata dan ibnu sabil (anak pungut) yang tidak mempunyai keluarga. Maka nashnash hukum tersebut tetap diartikan kepada pengartian 'urf yang pertama yaitu yang berlaku pada keluarnya nash-nash tersebut, karena pengertian itulah yang dikehendaki oleh syara', sedang pengertian nash-nash yang timbul sesudah keluarnya nash tidak menjadi pertimbangan. Oleh karena itu, berkata Imam Suyuti: "Suatu lafad akan di maknai 'urf apabila'urf yang menyertai dan mendahului bukan 'urf yang datang kemudian. Oleh karena fuqhoha' mengatakan: tidak ada pertimbangan terhadap 'urf yang datang kemudian. "43

Ketiga, Tidak ada penegasan (nash) yang berlawanan dengan 'urf. Penetapan hukum berdasarkan 'urf dalam hal ini termasuk dalam penetapan berdasarkan kesimpulan. Akan tetapi apabila penetapan tersebut berlawanan dengan penegasan, maka hapuslah penetapan tersebut. Oleh karena itu, suatu peminjaman barang dibatasi oleh orang yang meminjamkan, baik mengenai waktu, tempat, dan besarnya. Meskipun penegasan itu berlawanan dengan apa yang telah terbiasa. Jadi kalau seorang meminjam kendaran muatan dari orang lain, maka ia dianggap

${ }^{39}$ Musa Aripin, Eksistensi...,207.

${ }^{40}$ Shalih Ibn Ghanim al-Sadlan, al-Qawa'idu al-Fiqhiyatu al-Kubro wa ma Tafarra'a 'Anha, (Riyadh : Dar Balinsiyyah, 1417), 347.

${ }^{41}$ Faiz Zainuddin, "Konsep..., 400.

${ }^{42}$ Ahmad Hanafi, Pengantar Sejarah Hukum Islam, (Jakarta: PT Magenta Bhakti Guna, 1989), 94.

${ }^{43}$ Uyunul Bashoir fi Syarah As Bah wan Nadhoir. Juz II. 158. Maktabah as-Syamilah. 
telah diizinkan untuk memberinya muatan menurut ukurannya yang biasa. Akan tetapi kalau pemiliknya dengan tegas menentukan batas-batasnya sendiri, meskipun berlawanan dengan kebiasaan, maka bagi yang peminjam tidak boleh melampaui batas-batas yang telah ditentukan. ${ }^{44}$

Keempat, Pemakaian 'urf tidak mengabaikan nash yang pasti dari syari'at. Dikarenakan nash-nash syara' harus prioritas atas 'urf apabila nash syara' digabungkan dengan 'urf maka 'urf tetap biasa dipakai. ${ }^{45}$

Lebih dari sekedar penetapan hukum, 'urf merupakan sebuah metode dalam 'ushul al-fiqh yang memberikan perhatian serius terhadap fenomena sosial. Artinya 'urf yang ada bisa kita gunakan dan kembangkan dalam suatu komunitas masyarakat untuk melakukan perubahan sosial di segala bidang aspek kehidupan. Sayangnya, penggunaan metode ini dalam studi keislaman terasa sudah dipretensikan sebagai metode istinbath hukum. Terlebih penggunaannya juga sering diperdebatkan dalam konteks tersebut. ${ }^{46}$

\section{Pengaplikasian 'Urf Dalam Fiqh Muamalah}

Begitu banyak dan begitu pentingnya peran 'urf dalam kehidupan umat, mengharuskan apapun bentuk keputusan baik hukum, ekonomi, maupun yang lainnya mengambil 'urf tersebut sebagai bahan pertimbangan untuk kemaslahatan. Tak lain adalah agar kebijakan itu, sesuai dengan konteks sosiologis-antropologis masyarakat di suatu tempat. Hampir tidak bisa kita temukan aspek kehidupan yang murni berasal dari "langit" tanpa adanya sentuhan budaya manusia.

Teori 'urf seperti yang dikatakan oleh Wahbah Zuhaili digunakan oleh fuqaha dalam berbagai macam persoalan muamalah. Misalnya diperbolehkannya akad istisna', demi memenuhi hajat masyarakat, meskipun transaksi itu dilakukan atas sesuatu yang tidak ada (ma'dum) ${ }^{47}$ Atau diperbolehkannya jual beli buah-buahan yang masih berada di pohon, apabila kedua belah pihak, khususnya pembeli, telah melihat secara langsung kondisi buah yang akan di beli. Seluruh atau sebagian dari pohon yang sama. Semua itu didasarkan pada penggunaan ' $u r f .{ }^{48}$

Sebelum menjelaskan secara komprehensif tentang akad istishna', Wahbah Zuhaili juga memberikan pengantar bahwa Islam, menghendaki kemudahan bagi umatnya. ${ }^{49}$ Syari'at dibentuk, tak lain adalah upaya untuk menuntut umat Islam dalam memenuhi hajatnya, meraih kemaslahatan. Oleh karena itu, sangat diperlukan ijtihad dalam rangka menghasilkan konstruksi hukum yang sesuai dengan hajat tersebut. Disyari'atkannya akad-akad salam atau salaf, istishna', merupakan hasil ijtihad ulama, dengan melakukan pengecualian (istisna) terhadap nash, atau kaidah umum. Karena ada Al-hajatu tanzilu manazilah al-dharuriyah dan al-Islam dinu al-yusra la' usra.

Bila dicermati secara seksama, berbagai akad yang ada dan berkembang selama ini, termasuk yang diterapkan oleh perbankan syari'ah merupakan hasil dari kearifan lokal atau 'urf masyarakat Arab sebelum Nabi Muhammad diutus. Banyak diketahui, Islam merupakan kota perdagangan yang tangguh, dengan menguasai lalu lintas perdagangan dunia. ${ }^{50}$ Komunitas

\footnotetext{
${ }^{4}$ Ibid, 97.

${ }^{45}$ Faiz Zainuddin, Konsep..., 401.

${ }^{46}$ Asmuni Mth, Menggugat Nalar Perbankan Syari’ah (Perspektif Legal Maxim), 10.

${ }^{47}$ Wahbah al-Zuhailiy, al-Wajiz fi Ushul al-Fiqh, (Damaskus : Dar al-Fikr, 1990), 99.

${ }^{48}$ Ibid. 100.

${ }^{49}$ Wahbah al-Zuhailiy, al-Fiqh al-Islam wa Adillatuhu, Jilid 5, (Damaskus : Dar al-Fikr, 1995), 3640.

${ }^{50}$ Lebih lanjut baca: Patricia Crone, Meccan Trade and the Rise of Islam, (New Jersey : Gorgias Press,
} 2004). 
pedagang Arab, kafilah-kafilah dagang, telah ada jauh sebelum Islam disebarkan oleh Muhammad SAW. Tidak salah bila M.W. Watt menulis, sebagaimana dikutip oleh Karim; "the Qur'an appeared not on the atmosphere of desert but in that of high finance...The Quraish's financial skill and thire possession of the sacred territory had made economic masters of Western Arabia about a hundred years before prophet. ${ }^{51}$

Terbebas dari perdebatan fikih, khususnya di bidang muamalah, turut terpengaruh oleh hukum Romawi, sebagaimana dapat dibaca dalam buku Hukum Islam dan Hukum Romawi; Pengaruh atas Hukum Lama terhadap Hukum Baru, harus diakui akad-akad muamalah yang kita kenal sekarang, telah menjadi 'urf bangsa Arab dalam berniaga. ${ }^{52}$ Diutusnya Nabi Muhammad SAW, melanjutkan mekanisme perdagangan yang telah ada, namun dibangun prinsip-prinsip baru yang berkeadilan dan lebih mengedepankan kemaslahatan bersama, meninggalkan kemudharatan baik terhadap diri sendiri, maupun kepada pihak lain. Misalnya, hadist "aku pihak ketiga dari dua orang yang berserikat selama salah satunya tidak mengkhianati yang lainnya" (H.R. Abu Dawud). Bisa dicermati, bahwa hadist ini mengindikasikan sekaligus teguran bagi mereka yang melakukan kerjasama tetapi berkhianat.

Urf memainkan peran yang penting dalam pembentukan hukum Islam. Terlebih pada lingkup soalan muamalah. Bahkan 'Urf tidak bisa dilepaskan sebagai bagian dalam pertimbangan hukum. Tentunya juga bukanlah dalam rangka mengharamkan yang halal, ataupun sebaliknya. Wajar saja bila kaidah al-'urf atau tentang kearifan lokal, berada pada posisi qawaid kulliyat al-kubra.

\section{Penutup}

Permasalahan masyarakat yang semakin komplek menuntut adanya solusi dengan tepat namun tetap sesuai dengan ketentuan syariat. Untuk bisa dijadikan sebagai sumber hukum, maka 'urf harus memenuhi empat syarat diantaranya adalah sebagai berikut:

Pertama, 'Urf harus berlaku terus menerus atau kebanyakan berlaku. Yang dimaksud dengan terus menerus berlakunya adalah bahwa 'urf berlaku untuk semua peristiwa tanpa kecuali, sedang yang dimaksud dengan kebanyakan berlakunya ialah bahwa 'urf tersebut berlaku dalam kebanyakan peristiwa. Kedua, 'Urf yang dijadikan sumber hukum bagi suatu tindakan harus terdapat pada waktu diadakannya tindakan tersebut. Jadi bagi 'urf yang timbul kemudian dari suatu perbuatan tidak biasa dipegangi, dan hal ini untuk menjaga kesetabilan ketentuan suatu hukum. Ketiga, Tidak ada penegasan (nash) yang berlawanan dengan 'urf. Penetapan hukum berdasarkan 'urf dalam hal ini termasuk dalam penetapan berdasarkan kesimpulan. Akan tetapi apabila penetapan tersebut berlawanan dengan penegasan, maka hapuslah penetapan tersebut. Keempat, Pemakaian 'urf tidak akan mengakibatkan dikesampingkannya nash yang pasti dari syari at. Sebab nash-nash syara' harus didahulukan atas 'urf.

\section{DAFTAR PUSTAKA}

Al-Sadlan, Shalih Ibn Ghanim, al-Qawa'idu al-Fiqhiyatu al-Kubro wa ma Tafarra'a 'Anha, Riyadh: Dar Balinsiyyah, 1417.

${ }^{51}$ M. Abdul Karim, Islam di Asia Tengah; Sejarah Dinasti Mongol Islam, (Yogyakarta : Bagaskara, 2006),

8.

52 Muhammad Hamidullah, dkk., Fikih Islam \& Hukum Romawi Refleksi atas Pengaruh Hukum Lama terhadap Hukum Baru, (Yogyakarta : Gama Media, 2003). 
Al-Zuhailiy, Wahbah., Al-Wajiz fi Ushul al-Fiqh, Damaskus: Dar al-Fikr, 1990.

Al-Zuhailiy, Wahbah., Al-Figh al-Islam wa Adillatuhu, Jilid 5, Damaskus: Dar al-Fikr, 1995.

Aripin, Musa., "Eksistensi Urf Dalam Kompilasi Hukum Islam", Al-Maqasid, Volume 2 Nomor 12016.

Azam, Abdul Aziz Muhammad., Al-Qowaidul Fiqhiyah, Mesir: Darul Hadist, 2005.

Crone, Patricia., Meccan Trade and the Rise of Islam, New Jersey: Gorgias Press, 2004.

Hamidullah, Muhammad., dkk., Fikih Islam \& Hukum Romawi Refleksi atas Pengaruh Hukum Lama terhadap Hukum Baru, Yogyakarta: Gama Media, 2003.

Hanafi, Ahmad., Pengantar dan Sejarah Hukum Islam, Jakarta: Bulan Bintang, 1991.

Hanafi, Ahmad., Pengantar Sejarah Hukum Islam, Jakarta: Magenta Bhakti Guna, 1989.

Hariri, Ibrahim Muhammad Mahmud., Al-Madkhal ila Qowaidul Fiqhiyah.

Hasyiyah Raddul Muhtar, Juz I, al-Maktaba as-Syamilah.

Ibrahim, Abu Ishaq Bin Musa al-Syatibi., Al-Muafakat fi Ilmi Ushul Fiqh, Juz II, Beirut: Darul Fikr, 2005.

Ifrosin., Fiqh Adat (Tradisi Masyarakat Dalam Pandangan Fiqh), Jawa Tengah: Mukjizat, 2007. Jumantoro, Totok., Kamus Ilmu Ushul Fiqh, Jakarta: Amzah, 2005.

Karim, M. Abdul., Islam di Asia Tengah; Sejarah Dinasti Mongol Islam, Yogyakarta: Bagaskara, 2006.

Khalil, Rasyad Hasan., Tarikh Tasryi', Jakarta: Amzah, 2009.

Khallaf, 'Abdul Wahhab., 'Ilm Al-Ushul Al-Fiqh, Mesir: Dar Al-Qalam, Cet. Ke-12, 1978.

Khallaf, Abdul Wahab., Ushul Fiqh, Jakarta: Dar Al-Kutub Al-Islamiyah, 2010.

Khallaf, Abdul Wahab., Ilmu Ushul Fiqh, Jakarta: Rineka Cipta, 2012.

Khallaf, Abdul Wahab., Ilmu Ushul Fiqh (Kaidah Hukum Islam), Jakarta:Pustaka Amani.

Rofam, Galuh Nashrullah Kartika Mayangsari., "Penerapan Konsep 'Urf Dalam Kitab Sabilal Muhtadin (Kajian Terhadap Pemikiran Muhammad Arsyad Al Banjari)”, Al-Iqtishadiyah, Jurnal Ekonomi Syariah Dan Hukum Ekonomi Syariah, Volume: IV, Nomor I, Juni 2018.

Setiyawan, Agung., "Budaya Lokal Dalam Perspektif Agama: Legitimasi Hukum Adat ('Urf) dalam Islam", Esensia Vol. XIII, No. 2 Juli 2012.

Siddiq, Muhammad Bin Ahmad., Al-Wajiz fi Idhah al-Qawaid, Bairut: Muassasah al-Rissalah, 1983.

Syarifuddin, Amir., Ushul Fiqh, Jakarta: Logos Wacana Ilmu, 1997.

Syarifuddin, Amir., Ushul Fiqh, jilid 2, Jakarta : Logos, 2001.

Syarifuddin, Amir., Ushul Fiqh, Jilid 2, Jakarta: Prenada, 2009.

Umar, M., Study Ushul Fiqh, Jakarta, 1987.

Uyunul Bashoir fi Syarah As Bah wan Nadhoir, Juz II, Maktabah as-Syamilah.

Zainuddin, Faiz., "Konsep Islam Tentang Adat: Telaah Adat Dan Urf Sebagai Sumber Hukum Islam”, Jurnal Lisan Al-Hal, Volume 9, No. 2, Desember 2015. 